\title{
Serum immunoreactivity of cancer/testis antigen OY-TES-1 and its tissues expression in glioma
}

\author{
XISHENG LI ${ }^{1}$, JUN YAN ${ }^{1}$, RONG FAN ${ }^{2}$, BIN LUO ${ }^{3}$, QINGMEI ZHANG ${ }^{2}$, YONGDA LIN $^{2,3}$, \\ SUFANG ZHOU ${ }^{2}$, GUORONG LUO ${ }^{2}$, XIAOXUN XIE ${ }^{2,3}$ and SHAOWEN XIAO ${ }^{1}$ \\ ${ }^{1}$ Department of Neurosurgery, The First Affiliated Hospital of Guangxi Medical University; \\ ${ }^{2}$ Department of Histology and Embryology, and ${ }^{3}$ Central Laboratory, School of Pre-Clinical Medicine, \\ Guangxi Medical University, Nanning, Guangxi 530021, P.R. China
}

Received August 2, 2015; Accepted January 10, 2017

DOI: $10.3892 / 01.2017 .5799$

\begin{abstract}
OY-TES-1 is a member of the cancer/testis antigen family that is expressed in healthy testis tissue and certain types of cancerous tissue. The present study aimed to analyze the expression pattern of OY-TES-1 and serum anti-OY-TES-1 antibody concentration in patients with glioma. OY-TES-1 mRNA was detected in 28/36 (78\%) of glioma cases using conventional reverse transcription polymerase chain reaction (RT-PCR) analysis. RT-quantitative-PCR revealed that OY-TES-1 was expressed at a higher level in glioma tissues compared with normal adult tissues (with the exception of testis tissue). Anti-OY-TES-1 antibodies were present in the serum of $5 / 36(14 \%)$ of patients with glioma, but absent in all the serum samples from 107 healthy donors. Immunohistochemical analysis demonstrated that OY-TES-1 protein was expressed in all glioma tissues from patients with anti-OY-TES-1 antibody seropositivity. These results suggest that OY-TES-1 is a novel candidate for glioma immunotherapy.
\end{abstract}

\section{Introduction}

Glioma is one of the most common primary intracranial tumors of the central nervous system, with an annual incidence of $\sim 6 / 100,000$ individuals in the USA (1), accounting for $40-50 \%$ of brain tumors. The median survival time of patients with glioblastoma multiforme (GBM), the most aggressive

Correspondence to: Dr Shaowen Xiao, Department of Neurosurgery, The First Affiliated Hospital of Guangxi Medical University, 22 Shuangyong Road, Nanning, Guangxi 530021, P.R. China

E-mail: xsw57@yahoo.com

Dr Xiaoxun Xie, Department of Histology and Embryology, School of Pre-Clinical Medicine, Guangxi Medical University, 22 Shuangyong Road, Nanning, Guangxi 530021, P.R. China

E-mail: xiaoxunxie@hotmail.com

Key words: cancer/testis antigen, OY-TES-1, humoral immune response, glioma subtype of malignant glioma, is 12-16 months (2). Despite the advances made in multimodal treatment, including surgery, radiotherapy and chemotherapy, the prognosis for the majority of patients with malignant glioma remains poor, with a median survival time of 14.6 months (3). Therefore, the development of novel therapeutic strategies is required.

A potential lifespan-prolonging approach for patients with glioma is to administer immunotherapy during the course of treatment (4). This approach requires suitable tumor antigens with specific characteristics, including high expression levels in glioma tissues, restricted expression levels in normal tissues and inherent immunogenicity. The expression of a potential tumor antigen, cancer/testis (CT) antigen, is restricted to adult testicular germ cells under normal conditions, but aberrantly activated and expressed in a range of tumor types such as melanoma, bladder, breast, prostate, liver, ovarian, colon and non-small cell lung cancer (5-9). As the testes do not express major histocompatibility complex class I, cytotoxic T lymphocytes do not target the CT antigens expressed in the testis (10). At present, CT antigens are considered to be novel targets for immunotherapy in various tumor types, including glioma $(11,12)$.

OY-TES-1, a member of the CT antigen family, is the human homolog of proacrosin binding protein sp32, which was originally identified in pigs, guinea pigs and mice $(13,14)$. OY-TES-1 has been the subject of numerous recent studies (15-17) due to its expression in various cancerous tissues and restricted expression in normal tissues. Furthermore, OY-TES-1 is able to increase the humoral immune response across a broad spectrum of cancer types, including that of the bladder, prostate, liver, colon, lung and ovaries $(13,15,18)$. To the best of our knowledge there is no data available at present regarding the expression profile and immunogenicity of OY-TES-1 in patients with brain tumors. Whether OY-TES-1 is expressed in glioma tissue, and induces an immune response in patients with glioma, requires further investigation. Therefore, the present study was performed to examine the expression levels and serum immunoreactivity of OY-TES-1 in human glioma.

\section{Materials and methods}

Patients and specimens. The use of human tissue specimens in the present retrospective study was approved by the Ethics 
Committee of the First Affiliated Hospital of Guangxi Medical University (Nanning, China) and the written informed consent was obtained from all patients included in this study. A total of 36 tumor tissue samples (11 GBM, 7 anaplastic astrocytoma, 11 diffuse astrocytoma, 4 pilocytic astrocytoma, 1 anaplastic ependymoma, 1 pleomorphic xanthoastrocytoma and 1 ependymoma) and preoperative serum samples were obtained from in-patients at the Department of Neurosurgery at the First Affiliated Hospital of Guangxi Medical University between March 2013 and March 2014. Their clinical data were retrospectively reviewed. All patients underwent resection of the primary tumor and did not receive radiotherapy or chemotherapy prior to surgery. The mean patient age was 36.4 years (range, 3-65) and the gender distribution was 21 males and 15 females. All tumor specimens were classified according to the World Health Organization (WHO) criteria (19), with 17 cases of WHO grade I-II (low-grade) and 19 cases of WHO grade III-IV (high-grade) identified. Serum samples from 107 healthy donors (54 male; 53 female) and 7 types of normal tissue samples (3 testis, 3 kidney, 3 thyroid, 3 appendix, 3 spleen, 3 tonsil and 3 normal brain) were collected between May 2013 and March 2014 and were used as controls.

Reverse transcription polymerase chain reaction (RT-PCR) analysis. Total RNA was isolated from frozen tumor tissues using the RNAsimple Total RNA kit (TianGen Biotech Co., Ltd., Beijing, China), according to the protocol of the manufacturer. The concentration of isolated RNA was determined by spectrophotometer (SmartSpec ${ }^{\mathrm{TM}}$ plus; Bio-Rad Laboratories, Inc., Hercules, CA, USA), then $4 \mu$ g total RNA was reverse-transcribed into single-stranded cDNA with PrimeScript II First Strand cDNA Synthesis kit (Takara Biotechnology Co., Dalian, China). The integrity of obtained cDNA was tested by amplification of p53 transcripts in a 30 -cycle PCR reaction as previously described (20). The OY-TES-1 gene was amplified using established primers (21). The PCR reactions were in a total volume of $25 \mu$ containing $0.125 \mu \mathrm{l}$ of Takara Ex Taq HS (Takara Biotechnology Co.), $0.5 \mu \mathrm{l}$ of $10 \mu \mathrm{m} / 1$ forward primer, $0.5 \mu \mathrm{l}$ of $10 \mu \mathrm{m} / 1$ reverse primer, $5 \mu \mathrm{l}$ of $5 \mathrm{X}$ buffer, $18.375 \mu \mathrm{l}$ of RNase-free $\mathrm{H}_{2} \mathrm{O}$ and $0.5 \mu 1$ of cDNA. The cycling parameters were as follows: Initial denaturation at $94^{\circ} \mathrm{C}, 5 \mathrm{~min}$; denaturation at $94^{\circ} \mathrm{C}$, $1 \mathrm{~min}$; annealing at $58^{\circ} \mathrm{C}, 1 \mathrm{~min}$; extension at $72^{\circ} \mathrm{C}, 2 \mathrm{~min}$, for 35 cycles; and final extension at $72^{\circ} \mathrm{C}, 8 \mathrm{~min}$. Tumor protein (p)53 served as an internal control for normalization, as previously described (20). The quality of the RNAs and the PCR product was examined by electrophoresis on $1 \%$ agarose gel and observed under Gel Documentation and Analysis system (Uvipro 7600Z; UVItec Ltd., Cambridge, UK).

Reverse transcription quantitative PCR (RT-qPCR). The presence of OY-TES-1 mRNA was quantitatively detected using the $\mathrm{iCycler}_{\mathrm{iQ}}{ }^{\mathrm{TM}}$ Multi-Color Real-Time PCR Detection system (Bio-Rad Laboratories, Inc.) with the following primer sequences: Sense, 5'-GCGACACCTCCCACAAGAC-3' and antisense, 5'-GCCCACCGTACAAATCCAG-3'. The following 6-carboxyfluorescin (FAM)-labeled TaqMan probe was also used: 5'-FAM CAACCAGGTAGGGTCC TAMRA-3'. The amplified product consisted of a $123 \mathrm{bp}$ segment of the OY-TES-1 gene. The PCR reactions were in a total volume of
$25 \mu \mathrm{l}$ containing $2.5 \mu \mathrm{l}$ 10xbuffer, $5 \mu \mathrm{l} 25 \mathrm{mM} \mathrm{MgCl}_{2}, 1 \mu \mathrm{l}$ $2.5 \mathrm{mM}$ dNTP, $0.75 \mu \mathrm{l} 10 \mu \mathrm{M}$ forward primer, $0.75 \mu \mathrm{l} 10 \mu \mathrm{M}$ reverse primer, $1 \mu \mathrm{l} 10 \mu \mathrm{M}$ probe primer, $12 \mu \mathrm{l}$ RNase-free $\mathrm{H}_{2} \mathrm{O}$ and $2 \mu \mathrm{cDNA}$ template. Thermocycling conditions were as follows: $95^{\circ} \mathrm{C}$ for $2 \mathrm{~min}$, followed by 40 cycles of $95^{\circ} \mathrm{C}$ for $5 \mathrm{sec}$ and $60^{\circ} \mathrm{C}$ for $20 \mathrm{sec}$. The target OY-TES-1 mRNA was quantified by measuring the $\mathrm{Cq}$ value (22). The $\mathrm{Cq}$ value was defined as the threshold cycle number at which the fluorescence generated by cleavage of the probe passed above the baseline value. The value of the target OY-TES-1 mRNA in each sample was normalized to hypoxanthine phosphoribosyl transferase (HPRT) amplification (23). All samples were run in triplicate.

ELISA analysis. Serum antibody against OY-TES-1 was detected by ELISA, as described previously (15). The recombinant OY-TES-1 protein (15) and maltose binding protein (MBP; blank control) (15) were diluted serially from 1:100 to $1: 3,200$, coated onto 96 -well plates and incubated at $4{ }^{\circ} \mathrm{C}$ overnight. Subsequently, the plates were blocked with $5 \%$ nonfat milk and incubated with serum (1:400; $100 \mu \mathrm{l} /$ well) at $37^{\circ} \mathrm{C}$ for $1 \mathrm{~h}$, followed by incubation with horseradish peroxidase (HRP)-conjugated sheep anti human IgG (cat. no. 109-035-003; dilution, 1:5,000; Jackson ImmunoResearch, West Grove, PA, USA). Finally, the plates were incubated with 3,3',5,5'-tetramethylbenzidine at room temperature for $20 \mathrm{~min}$, and $2 \mathrm{~mol} / \mathrm{l}$ sulfuric acid was added to terminate the reaction. The absorbance was measured at a wavelength of $450 \mathrm{~nm}$ using a microplate reader. The healthy donor serum samples were used as negative controls. All the serum samples were evaluated $\geq 2$ times. A positive reaction was defined as an optical density (OD) value that exceeded the mean OD of the healthy donor sera by three standard deviations.

Immunohistochemistry (IHC). IHC was performed using the tissue samples from patients with glioma who were anti-OY-TES-1 antibody seropositive. The testis and normal brain tissues were used as positive and negative controls, respectively. The IHC procedure was performed according to a previous protocol (15). In brief, deparaffinized tissue sections underwent heat-based antigen retrieval in citrate buffer ( $\mathrm{pH}$ 6.0, $10 \mathrm{mM}$ ). Following the inactivation of endogenous peroxidase, the tissue sections were incubated with an anti-OY-TES-1 primary antibody (cat. no. ab64809; dilution, 1:1,000; Abcam, Cambridge, UK) or rabbit pre-immune serum (negative control) (15) at $4^{\circ} \mathrm{C}$ overnight. Subsequently, the tissue sections were washed and incubated with a HRP-labeled goat anti-rabbit IgG (cat. no. D-3004; dilution, 1:500; Shanghai Long Island Biotec, Shanghai, China) at room temperature for $1 \mathrm{~h}$, labeled with 3,3'-diaminobenzidine and counterstained with hematoxylin. Then they were viewed under an optical microscopy (Olympus BX53; Olympus Corporation, Tokyo, Japan).

Sequencing analysis. The open reading frame (ORF) of OY-TES-1 was amplified from the cDNA of tumor tissues using PCR with specific primers as follows: Sense, 5'-GCGGC GGATCTTCTCCGGCCATG-3' and antisense, 5'-ACGGGAT CCTTATCAGTTGGGCTGGGGTGT-3'. A total of 35 PCR amplification cycles were performed, each consisting of 
Table I. Association between OY-TES-1 mRNA expression and serum anti-OY-TES-1 antibody and the clinicopathological characteristics of patients with glioma.

\begin{tabular}{|c|c|c|c|c|}
\hline $\begin{array}{l}\text { Clinicopathological } \\
\text { characteristic }\end{array}$ & $\begin{array}{c}\text { No. of mRNA } \\
\text { positive patients/total (\%) }\end{array}$ & P-value & $\begin{array}{l}\text { No. of serum anti-OY-TES-1 } \\
\text { antibody positive patients/total (\%) }\end{array}$ & P-value ${ }^{a}$ \\
\hline \multicolumn{5}{|l|}{ Gender } \\
\hline Male & $16 / 21(76.2)$ & 1.00 & $3 / 21(14.3)$ & 1.00 \\
\hline Female & $12 / 15(80.0)$ & & $2 / 15(13.3)$ & \\
\hline \multicolumn{5}{|l|}{ Age, years } \\
\hline$<30$ & 9/13 (69.2) & 0.42 & $3 / 13(23.1)$ & 0.34 \\
\hline$\geq 30$ & $19 / 23(82.6)$ & & $2 / 23(8.67)$ & \\
\hline \multicolumn{5}{|l|}{ WHO tumor grade } \\
\hline I-II & 13/17 (76.5) & 1.00 & 3/17 (17.6) & 0.65 \\
\hline III-IV & $15 / 19(78.9)$ & & $2 / 19(10.5)$ & \\
\hline
\end{tabular}

${ }^{\text {a } P-v a l u e s ~ w e r e ~ c a l c u l a t e d ~ u s i n g ~ F i s h e r ' s ~ e x a c t ~ t e s t . ~ W H O, ~ W o r l d ~ H e a l t h ~ O r g a n i z a t i o n . ~}$

denaturation at $98^{\circ} \mathrm{C}$ for $10 \mathrm{sec}$, followed by annealing at $63^{\circ} \mathrm{C}$ for $15 \mathrm{sec}$ and extension at $72^{\circ} \mathrm{C}$ for $2 \mathrm{~min}$. The final extension step was performed at $72^{\circ} \mathrm{C}$ for $10 \mathrm{~min}$. PCR products were purified and ligated into pMD8-T vectors (Takara Biotechnology Co.), which were transformed into DH5 $\alpha$ competent cells (Beijing TransGen Biotech Co., Ltd., Beijing, China) (24). The transformed cells were smeared on LB-ampicillin agar plates containing X-gal. White colonies were screened and then inoculated into $5 \mathrm{ml}$ bacterial culture medium overnight. Plasimid was extracted by EZ Spine Column Plasimid Mini-Preps kit (Sangon Biotechnology Co., Shanghai, China) and verified by $\mathrm{PCR}$, as previously described (21). Clones with the correct insertion were identified via Sanger sequencing in 3730XL DNA Analyzer (Sino Genomax Co., Ltd., Beijing, China).

Statistical analysis. Results are presented as the mean $\pm(\mathrm{SD})$. All statistical analyses were performed using SPSS version 15.0 (SPSS Inc., Chicago, IL, USA). The association between gene expression levels, the presence of antibodies in the sera and the clinicopathological characteristics of patients with glioma was evaluated using Fisher's exact test. The expression levels of OY-TES-1, relative to HPRT, in glioma samples of different WHO grades and normal tissues were compared using the Mann-Whitney $\mathrm{U}$ test. $\mathrm{P}<0.05$ was considered to indicate a statistically significant difference.

\section{Results}

OY-TES-1 mRNA expression is upregulated in glioma. To examine the presence of OY-TES-1 mRNA in glioma, conventional RT-PCR was initially performed to detect OY-TES-1 transcription. A total of $78 \%(28 / 36)$ of the glioma tissue samples were OY-TES-1 mRNA positive (Fig. 1A), with 76\% (13/17) of low-grade tumors and 79\% (15/19) of high-grade tumors positive for OY-TES-1 mRNA. Subsequently, the association between OY-TES-1 mRNA expression and the clinicopathological characteristic of patients with glioma, including gender, age and WHO tumor grade, were examined. As presented in Table I, no significant association was
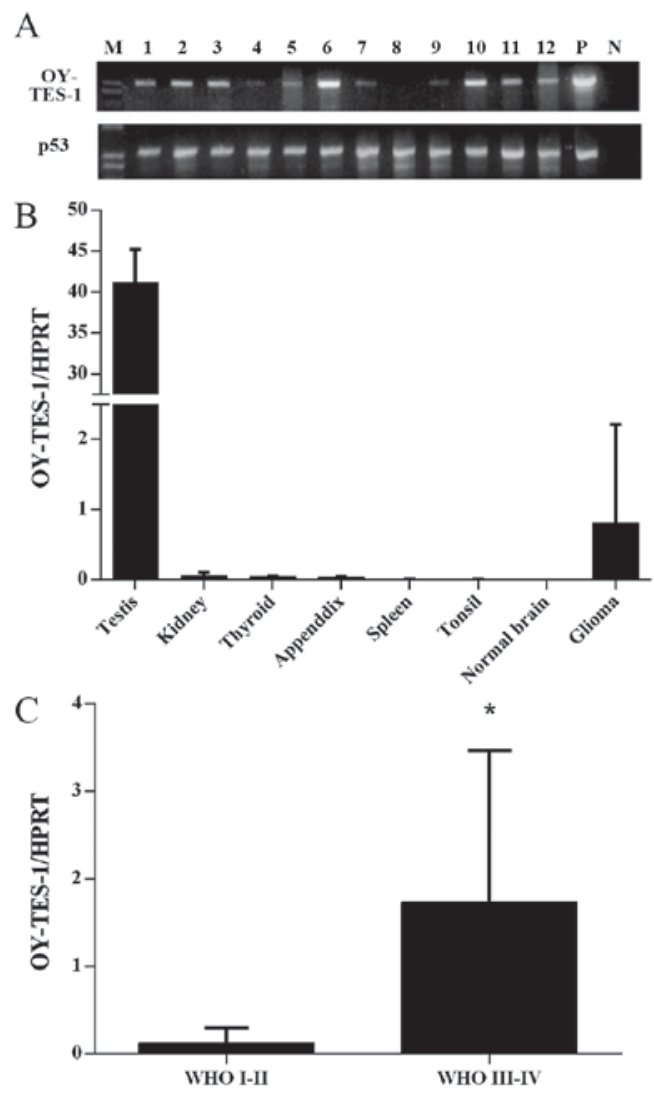

Figure 1. Expression of OY-TES-1 mRNA in glioma tissue. (A) Representative 12 RT-PCR results of OY-TES-1 expression in glioma (lanes 1-12), positive control testis samples (lane P) and negative controls with no cDNA (lane N). p53 was amplified as the internal control. (B) RT-qPCR analysis of OY-TES-1 mRNA. OY-TES-1 mRNA was elevated in glioma tissues compared with normal adult tissues, with the exception of testis tissue. The levels of OY-TES-1 mRNA in glioma tissues were significantly higher than in normal brain tissues $(\mathrm{P}=0.0015)$. (C) Comparison of OY-TES-1 mRNA between WHO grade I-II and III-IV glioma tissues, as examined by RT-qPCR. The level of OY-TES-1 mRNA was significantly higher in high-grade compared with low-grade glioma samples ( $\mathrm{P}=0.0002$ vs. WHO I-II). Results are presented as the mean \pm standard deviation. RT-PCR, reverse transcription-polymerase chain reaction; RT-qPCR, reverse transcription-quantitative polymerase chain reaction; p53, tumor protein 53; WHO, World Health Organization; HPRT, hypoxanthine phosphoribosyl transferase. 
A

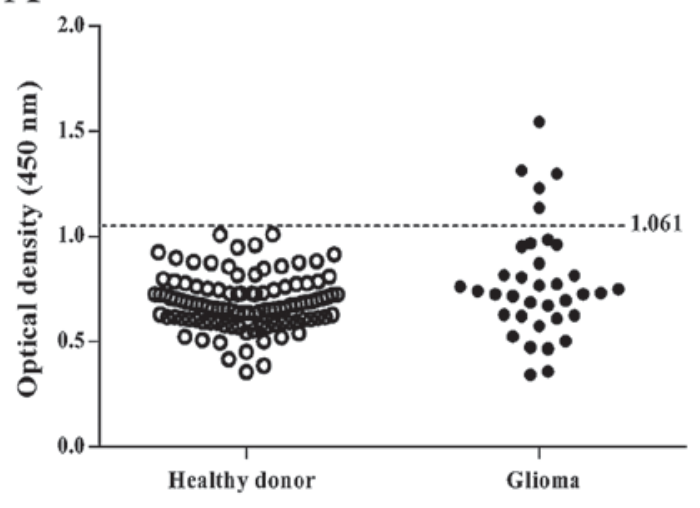

B

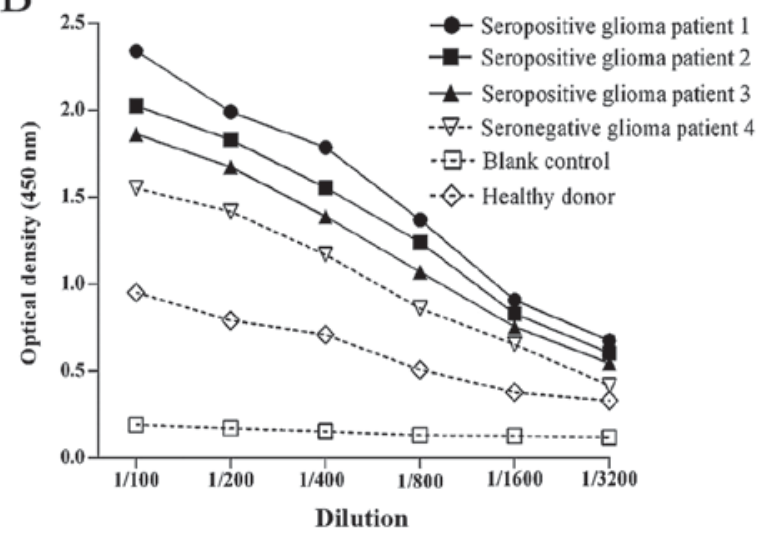

Figure 2. ELISA analysis of the anti-OY-TES-1 antibody in the sera of patients with glioma. (A) Detection of anti-OY-TES-1 antibodies in the sera of 36 patients with glioma and 107 healthy donors. A total of three standard deviations over the mean absorbance in the sera from normal donors was used as the cut-off value (1.061) for a positive result (indicated by the dotted line). (B) Serum titration curves of a dilution series of recombinant OY-TES-1 protein was produced at five concentrations. Sera from 4 representative patients and 1 healthy donor are presented.

A a-1


a-2

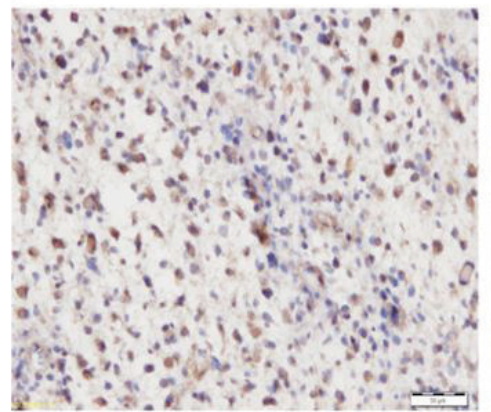

$\mathrm{B}$

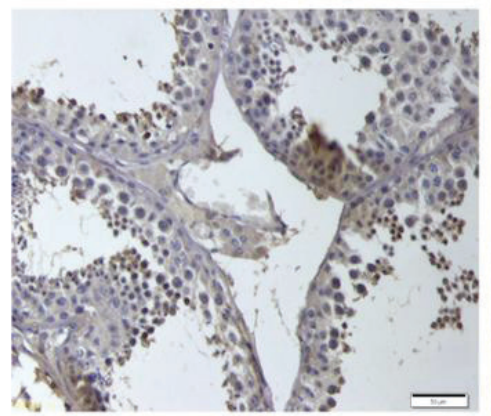

a-3

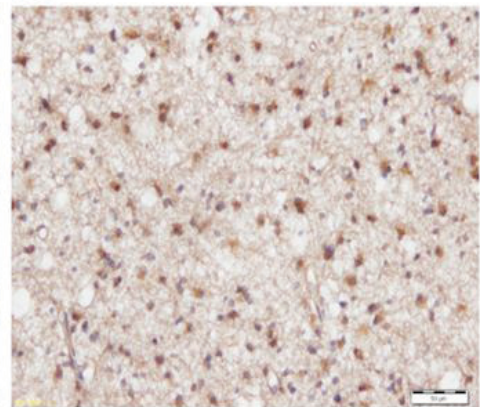

$\mathrm{C}$



Figure 3. Immunohistochemical staining for the OY-TES-1 protein in glioma tissue, normal testis and brain tissue samples. (A) Glioma tissues exhibited a varied intensity of immunostaining for the OY-TES-1 protein in the cytoplasm and nuclei of tumor cells. (B) Seminiferous tubules exhibited OY-TES-1 protein immunostaining in the normal testis, primarily in the late stages of spermatogenesis. (C) Normal brain tissue exhibited no OY-TES-1 protein immunostaining. Scale bar, $50 \mu \mathrm{m}$.

observed between the expression of OY-TES-1 mRNA and the clinicopathological parameters.

As a high frequency of OY-TES-1 mRNA expression was present in the glioma tumor samples, the expression pattern of OY-TES-1 mRNA was further examined. RT-qPCR analysis demonstrated that the OY-TES-1 mRNA expression levels in glioma tissues were markedly elevated compared with normal tissues (with the exception of testis tissue); but significantly higher than normal brain tissues $(\mathrm{P}=0.0015$; Fig. 1B). The RT-qPCR results also revealed that high-grade tumors expressed significantly higher levels of OY-TES-1
mRNA compared with low-grade tumors $(\mathrm{P}=0.0002$; Fig. 1C).

Anti-OY-TES-1 antibody is present in the patient serum samples. The expression of serum antibodies directed against OY-TES-1 was analyzed in 36 patients with glioma and 107 healthy donors by ELISA analysis. The OY-TES-1 antibody was detected in the serum of 5/36 (14\%) patients with glioma, whereas the sera of all healthy donors were negative for the anti-OY-TES-1 antibody (Fig. 2A). Titration curves were produced for anti-OY-TES-1 antibody-positive 
and -negative sera from representative patients with glioma, in addition to a healthy donor control, using the recombinant OY-TES-1 protein (Fig. 2B). The possibility of an association between the presence of antiOY-TES-1 antibodies in the sera and the clinicopathological characteristics of patients with glioma was evaluated, but no statistically significant association was identified (Table I).

OY-TES-1 protein is detectable in glioma tissues from anti-OY-TES-1 antibody seropositive patients. As the glioma tissues from the 5 anti-OY-TES- 1 antibody seropositive patients were all positive for the presence of OY-TES-1 mRNA, the expression of the OY-TES-1 protein in glioma tissues was examined (Fig. 3). IHC detected the OY-TES-1 protein in all the glioma tissue. Furthermore, it was observed that OY-TES-1 protein was primarily localized in the cytoplasm of the tumor cells, with occasional positive staining in the nuclei. In certain cases, heterogeneity of OY-TES-1 protein expression was observed in tumor tissues.

No aberrance is observed in the ORF of OY-TES-1 in glioma tissues from anti-OY-TES-1 antibody seropositive patients. To determine whether the humoral immune response against OY-TES-1 in the patients with glioma was due to an aberrance in this gene, the full-length ORF of the OY-TES-1 gene was amplified from the tumor tissues of anti-OY-TES-1 antibody seropositive patients and sequenced. No aberrant changes, including mutations, deletions or insertions, were detected in the ORF of the OY-TES-1 gene (data not shown).

\section{Discussion}

As a member of the CT antigen family, OY-TES-1 is listed in the database of the Ludwig Institute for Cancer Research (Brussels, Belgium) (25), in which it is also named as CT23. OY-TES-1 is frequently expressed at the mRNA level in various types of cancer $(13,15,18)$. OY-TES-1 protein is expressed in $\sim 60 \%$ of ovarian (15) and $43 \%$ of colorectal (18) tumors. To the best of our knowledge, OY-TES-1 expression patterns at the mRNA and protein level, and its immunogenicity in brain tumors, including glioma, have yet to be elucidated.

The present study demonstrated that $78 \%$ of the glioma tissue samples expressed OY-TES-1 mRNA, which was detected via conventional RT-PCR. The levels of OY-TES-1 expression were high compared with those observed in previous studies of OY-TES-1 mRNA expression using the same primers in other types of cancer, including bladder $(11 / 39,28 \%)$, breast $(2 / 5,40 \%)$, colon $(2 / 13,15 \%)$, liver $(2 / 5$, $40 \%)$, ovarian $(23 / 100,23 \%)$ and colorectal $(44 / 60,73 \%)$ cancer $(13,15,18)$. Due to the high proportion of glioma tissues in the present study that expressed OY-TES-1, the quantity of OY-TES-1 mRNA was investigated using RT-qPCR. The results revealed that OY-TES-1 mRNA expression was elevated in glioma, compared with a panel of normal tissues (with the exception of the testis) but significantly higher than normal brain tissues $(\mathrm{P}=0.0015)$. The data suggest that OY-TES-1 is a novel target for the treatment of glioma, from an immunotherapeutic standpoint.

The present study investigated the association between OY-TES-1 mRNA expression and the clinicopathological characteristics of patients with glioma. The data suggested that there is no significant association between the presence of OY-TES- 1 mRNA and clinicopathological characteristics in glioma; however, the level of OY-TES-1 mRNA was significantly higher in high-grade compared with low-grade glioma samples. It has been established that a higher grade of glioma is correlated with greater malignancy and a poorer prognosis (26). Therefore, the expression of OY-TES-1 mRNA may be used as a novel prognostic marker for glioma. Follow-up studies are required to further investigate the association between the quantity of OY-TES-1 mRNA and patient outcome.

Although the brain is located in an immune-privileged anatomical site, a humoral immune response to several tumor antigens has been detected in patients with glioma (27-29), suggesting that the brain is not completely immunoprivileged. The presence of antibodies against a number of tumor antigens has been examined in association with the survival of patients with glioma (30). The current study examined OY-TES-1 seroreactivity in patients with glioma, in addition to healthy individuals. The results demonstrated that $5 / 36(14 \%)$ of patients with glioma had the anti-OY-TES-1 antibody present in their serum, whereas this antibody was not expressed in any of the serum samples from healthy donors $0 / 107(0 \%)$. The anti-OY-TES-1 antibody has previously been observed in patients with other types of cancer, with a frequency of $4.8-40 \%(13,15)$. A previous study detected the presence of the anti-OY-TES-1 antibody in $9.6 \%$ of patients with colorectal cancer (15), a result concordant with data from the current study in patients with glioma. However, no significant association was identified between the presence of the anti-OY-TES-1 antibody in the serum and the clinicopathological characteristics of patients with glioma in the present study.

The molecular mechanisms underlying the immune response against OY-TES-1 in patients with glioma requires further investigation, as our serum immunoreactive result demonstrated that OY-TES-1 may possess immunogenic potential in patients with glioma. The present study utilized IHC to examine glioma tissues from anti-OY-TES-1 antibody seropositive patients. The results revealed that the OY-TES-1 protein was detectable in all the glioma tissue samples, and was primarily localized to the cytoplasm of tumor cells. As OY-TES-1 is not localized to the cell surface, it may be hypothesized that a mutation in the gene encoding OY-TES-1 may trigger a humoral immune response against OY-TES-1 in patients with brain tumors, in a similar manner to the mutated version of the p53 tumor suppressor gene detected in colon cancer and glioma, which raises the levels of the corresponding antibodies in patient's sera (31-32). However, the sequence analysis performed in the present study revealed no significant variation in the ORF of the OY-TES-1 gene, providing no support for this hypothesis.

Therefore, enhanced levels of OY-TES-1 expression may occur as a result of the immune response to cancer, as in the case of human epidermal growth receptor 2 , an oncogene that is amplified in certain types of cancer (33). A previous study suggested that large quantities of immunocompetent cells, including B lymphocytes, are able to invade the tissue of malignant gliomas with a large necrotic area (34), increasing the possibility of an interaction between immunocompetent 
cells and amplified gene products, which are able to function as antigens. An alternative hypothesis is that the humoral response against OY-TES-1 may be induced by the products of post-translational modifications of the OY-TES-1 protein. Previous studies have reported that sumoylated or hyperphosphorylated proteins may serve as autoimmunogenic targets, including sumoylated heat shock protein 90 (35) and hyperphosphorylated paratarg-7 (36). Thus, the presence of a humoral response against OY-TES-1 in patients with glioma may be a predictor of the cellular immune response, as is the case with NY-ESO-1, a CT antigen defined using serological analysis of recombinant expression libraries, in esophageal cancer (37).

In conclusion, the results of the present study indicated that OY-TES-1 mRNA is expressed in a high proportion of glioma tissues and possesses inherent immunogenicity. Therefore, it may present a novel target for specific immunotherapy in the treatment of brain tumors, particularly glioma. At present, determination of the prognosis using follow-up data and the cell-mediated immune response to OY-TES-1 is under investigation, which may aid understanding of the role of OY-TES-1 in tumorigenesis.

\section{Acknowledgements}

The present was supported by the National Natural Science Foundation of China (grant nos. 81360371 and 81360374), Guangxi Nature Science Foundation (grant nos. 0728148, 0832144 and 2011GXNSFA 018275) and the Guangxi Educational Bureau (grant no. BGXZ2007010). The authors would like to thank Ms. Fang Chen for her technical assistance.

\section{References}

1. Ostrom QT, Gittleman H, Liao P, Rouse C, Chen Y, Dowling J, Wolinsky Y, Kruchko C and Barnholtz-Sloan J: CBTRUS statistical report: Primary brain and central nervous system tumors diagnosed in the United States in 2007-2011. Neuro Oncol 16 (Suppl 4): iv1-iv63, 2014.

2. Naydenov E, Tzekov C, Minkin K, Nachev S, Romansky K and Bussarsky V: Long-term survival with primary glioblastoma multiforme: A clinical study in bulgarian patients. Case Rep Oncol 4: 1-11, 2011

3. Oike T, Suzuki Y, Sugawara K, Shirai K, Noda SE, Tamaki T, Nagaishi M, Yokoo H, Nakazato Y and Nakano T: Radiotherapy plus concomitant adjuvant temozolomide for glioblastoma: Japanese mono-institutional results. PLoS One 8: 78943, 2013.

4. Ehtesham M, Black KL and Yu JS: Recent progress in immunotherapy for malignant glioma: Treatment strategies and results from clinical trials. Cancer control 11: 192-207, 2004.

5. Zendman AJ, Ruiter DJ and Van Muijen GN: Cancer/testis-associated genes: Identification, expression profile, and putative function. J Cell Physiol 194: 272-288, 2003.

6. Scanlan MJ, Simpson AJ and Old LJ: The cancer/testis genes: Review, standardization, and commentary. Cancer Immun 4: 1, 2004

7. Kalejs $\mathrm{M}$ and Erenpreisa $\mathrm{J}$ : Cancer/testis antigens and gametogenesis: A review and 'brain-storming' session. Cancer Cell Int 5: 4, 2005.

8. Caballero OL and Chen YT: Cancer/testis (CT) antigens: Potential targets for immunotherapy. Cancer sci 100: 2014-2021, 2009.

9. Fratta E, Coral S, Covre A, Parisi G, Colizzi F, Danielli R, Nicolay HJ, Sigalotti L and Maio M: The biology of cancer testis antigens: Putative function, regulation and therapeutic potential. Mol Oncol 5: 164-182, 2011.

10. Okumura H, Noguchi Y, Uenaka A, Aji T, Ono T, Nakagawa K, Aoe M, Shimizu N and Nakayama E: Identification of an HLA-A24-restricted OY-TES-1 epitope recognized by cytotoxic T-cells. Microbiol Immunol 49: 1009-1016, 2005.
11. Yao J, Caballero OL, Yung WK, Weinstein JN, Riggins GJ, Strausberg RL and Zhao Q: Tumor subtype-specific cancer-testis antigens as potential biomarkers and immunotherapeutic targets for cancers. Cancer Immunol Res 2: 371-379, 2014.

12. Freitas M, Malheiros S, Stávale JN, Biassi TP, Zamunér FT, de Souza Begnami M, Soares FA and Vettore AL: Expression of cancer/testis antigens is correlated with improved survival in glioblastoma. Oncotarget 4: 636-646, 2013.

13. Ono T, Kurashige T, Harada N, Noguchi Y, Saika T, Niikawa N, Aoe M, Nakamura S, Higashi T, Hiraki A, et al: Identification of proacrosin binding protein $\mathrm{sp} 32$ precursor as a human cancer/testis antigen. Proc Natl Acad Sci USA 98: 3282-3287, 2001.

14. Baba T, Niida Y, Michikawa Y, Kashiwabara S, Kodaira K, Takenaka M, Kohno N, Gerton GL and Arai Y: An acrosomal protein, sp32, in mammalian sperm is a binding protein specific for two proacrosins and an acrosin intermediate. J Biol Chem 269: 10133-10140, 1994.

15. Luo B, Yun X, Fan R, Lin YD, He SJ, Zhang QM, Mo FR, Chen F, Xiao SW and Xie XX: Cancer testis antigen OY-TES-1 expression and serum immunogenicity in colorectal cancer: Its relationship to clinicopathological parameters. Int J Clin Exp Pathol 6: 2835-2845, 2013.

16. Fu J, Luo B, Guo WW, Zhang QM, Shi L, Hu QP, Chen F, Xiao SW and Xie XX: Down-regulation of cancer/testis antigen OY-TES-1 attenuates malignant behaviors of hepatocellular carcinoma cells in vitro. Int J Clin Exp Pathol 8: 7786-7797, 2015.

17. Fan R, Huang W, Luo B, Zhang QM, Xiao SW and Xie XX. Cancer testis antigen OY-TES-1: Analysis of protein expression in ovarian cancer with tissue microarrays. Eur J Gynaecol Oncol 36: 298-303, 2015.

18. Tammela J, Uenaka A, Ono T, Noguchi Y, Jungbluth AA, Mhawech-Fauceglia P, Qian F, Schneider S, Sharma S, Driscoll D, et al: OY-TES-1 expression and serum immunoreactivity in epithelial ovarian cancer. Int J Oncol 29: 903-910, 2006.

19. Louis DN, Ohgaki H, Wiestler OD, Cavenee WK, Burger PC, Jouvet A, Scheithauer BW and Kleihues P: The 2007 WHO classification of tumours of the central nervous system. Acta Neuropathol 114: 97-109, 2007.

20. Gure AO, Chua R, Williamson B, Gonen M, Ferrera CA, Gnjatic S, Ritter G, Simpson AJ, Chen YT, Old LJ and Altorki NK: Cancer-testis genes are coordinately expressed and are markers of poor outcome in non-small cell lung cancer. Clin Cancer Res 11: 8055-8062, 2005.

21. Cen YH, Guo WW, Luo B, Lin YD, Zhang QM, Zhou SF, Luo GR, Xiao SW and Xie XX: Knockdown of OY-TES-1 by RNAi causes cell cycle arrest and migration decrease in bone marrow-derived mesenchymal stem cells. Cell Biol Int 36: 917-922, 2012.

22. Livak KJ and Schmittgen TD: Analysis of relative gene expression data using real-time quantitative PCR and the 2(-Delta Delta C(T)) method. Methods 25: 402-408, 2001.

23. He SJ, Gu YY, Yu L, Luo B, Fan R, Lin WZ, Lan XW, Lin YD, Zhang QM, Xiao SW and Xie XX: High expression and frequently humoral immune response of melanoma-associated antigen D4 in glioma. Int J Clin Exp Pathol 7: 2350-2360, 2014.

24. Froger A and Hall JE: Transformation of plasmid DNA into E. coli using the heat shock method. J Vis Exp 253, 2007.

25. Almeida LG, Sakabe NJ, deOliveira AR, Silva MC, Mundstein AS, Cohen T, Chen YT, Chua R, Gurung S, Gnjatic S, et al: CTdatabase: A knowledge-base of high-throughput and curated data on cancer-testis antigens. Nucleic Acids Res 37: D816-D819, 2009.

26. Yang P, Wang Y, Peng X, You G, Zhang W, Yan W, Bao Z, Wang Y, Qiu X and Jiang T: Management and survival rates in patients with glioma in China (2004-2010): A retrospective study from a single-institution. J Neurooncol 113: 259-266, 2013.

27. Sahin U, Türeci O, Schmitt H, Cochlovius B, Johannes T, Schmits R, Stenner F, Luo G, Schobert I and Pfreundschuh M: Human neoplasms elicit multiple specific immune responses in the autologous host. Proc Natl Acad Sci USA 92: 11810-11813, 1995.

28. Fischer U, Struss AK, Hemmer D, Pallasch CP, Steudel WI and Meese E: Glioma-expressed antigen 2 (GLEA2): A novel protein that can elicit immune responses in glioblastoma patients and some controls. Clin Exp Immunol 126: 206-213, 2001.

29. Struss AK, Romeike BF, Munnia A, Nastainczyk W, Steudel WI, König J, Ohgaki H, Feiden W, Fischer U and Meese E: PHF3-specific antibody responses in over $60 \%$ of patients with glioblastoma multiforme. Oncogene 20: 4107-4114, 2001. 
30. Pallasch CP, Struss AK, Munnia A, König J, Steudel WI, Fischer U and Meese E: Autoantibodies against GLEA ${ }_{2}$ and $\mathrm{PHF}_{3}$ in glioblastoma: Tumor-associated autoantibodies correlated with prolonged survival. Int J Cancer 117: 456-459, 2005.

31. Scanlan MJ, Chen YT, Williamson B, Gure AO, Stockert E, Gordan JD, Türeci O, Sahin U, Pfreundschuh M and Old LJ: Characterization of human colon cancer antigens recognized by autologous antibodies. Int J Cancer 76: 652-658, 1998.

32. Weller M, Bornemann A, Ständer M, Schabet M, Dichgans J and Meyermann R: Humoral immune response to $\mathrm{p} 53$ in malignant glioma. J Neurol 245: 169-172, 1998.

33. Cheever MA, Disis ML, Bernhard H, Gralow JR, Hand SL, Huseby ES, Qin HL, Takahashi M and Chen W: Immunity to oncogenic proteins. Immunol Rev 145: 33-59, 1995.

34. Yamanaka R, Tanaka R and Saito T: Immunohistochemical analysis of tumor-infiltrating lymphocytes and adhesion molecules (ICAM-1, NCAM) in human gliomas. Neurol Med Chir (Tokyo) 34: 583-587, 1994.
35. Preuss KD, Pfreundschuh M, Weigert M, Fadle N, Regitz E and Kubuschok B: Sumoylated HSP90 is a dominantly inherited plasma cell dyscrasias risk factor. J Clin Invest 125: 2179, 2015.

36. Grass S, Preuss KD, Wikowicz A, Terpos E, Ziepert M, Nikolaus D, Yang Y, Fadle N, Regitz E, Dimopoulos MA, et al: Hyperphosphorylated paratarg-7: A new molecularly defined risk factor for monoclonal gammopathy of undetermined significance of the IgM type and Waldenstrom macroglobulinemia. Blood 117: 2918-2923, 2011.

37. Chen YT, Scanlan MJ, Sahin U, Türeci O, Gure AO, Tsang S, Williamson B, Stockert E, Pfreundschuh M and Old LJ: A testicular antigen aberrantly expressed in human cancers detected by autologous antibody screening. Proc Natl Acad Sci USA 94: 1914-1918, 1997. 